\title{
Structure of differed Marandu palisade grass with variables nitrogen doses and heights
}

Received: May, 2020; Accepted: Aug, 2020

\begin{abstract}
Flávia Soares ${ }^{1}$, Dilermando Miranda da Fonseca ${ }^{2}$, Davi Moraes de Oliveira ${ }^{1}$, Lorena Carla Adorno ${ }^{1}$, Kimberly Barcelos Gois ${ }^{1}$, Gustavo Segatto Borges ${ }^{1}$, Manoel Eduardo Rozalino Santos ${ }^{1^{*}}$
\end{abstract}

\begin{abstract}
This study aims to evaluate the effects of height (15 and $30 \mathrm{~cm})$ and nitrogen dose $\left(\mathrm{N}, 40,80\right.$, and $\left.120 \mathrm{~kg} \mathrm{ha}^{-1}\right)$ at the beginning of the stockpiling period on the structural characteristics of the Urochloa brizantha cv. Marandu (Marandu palisade grass) during winter. The falling index of the plant did not vary with the factors under scrutiny $(\mathrm{P}>0,10)$. The number of basal tillers was higher $(\mathrm{P} \leq 0,10)$ in the $15-\mathrm{cm}$ deferred canopy than in the 30-cm canopy only when the highest $\mathrm{N}$ dose was used. Under conditions of application of 0 or $80 \mathrm{~kg} \mathrm{ha}^{-1}$ of $\mathrm{N}$, the $30-\mathrm{cm}$ stockpiled canopies showed a higher $(\mathrm{P} \leq 0,10)$ forage mass than the $15-\mathrm{cm}$ ones. Associated with reduced canopy height at the beginning of stockpiling period, nitrogen fertilization improves the morphological composition of Marandu palisade grass. To maximize the forage mass in the dry season, the canopies of Marandu palisade grass can be deferred either at $15 \mathrm{~cm}$ (fertilized with about $100 \mathrm{~kg} \mathrm{ha}^{-1}$ of N) or at $30 \mathrm{~cm}$ (with no nitrogen fertilization) at the beginning of the stockpiling period.
\end{abstract}

Keywords: Brachiaria brizantha; falling index; forage mass; morphological composition; Urochloa brizantha.

\section{Introduction}

Forage production in tropical regions is divided into two periods. During the dry season in the Southeast and Midwest regions of Brazil, Urochloa grasses produces only 10 to $23 \%$ of the annual forage production, the rainy season on the other hand, produces up to $90 \%$ of the annual

\footnotetext{
${ }^{1}$ School of Veterinary Medicine, Federal University of Uberlândia

${ }^{2}$ Departament of Zootechnics, Federal University of Viçosa

* Corresponding author: manoel.rozalino@ufu.br, Faculdade de Medicina Veterinária - Universidade Federal de Uberlândia, Campus Glória - Bloco 1CCG, BR-050 - KM 78 - Bairro Glória, Uberlândia MG CEP 38410-337
} 
production. (Pizarro, Valle, Séller-Grein, Schultzekraft, \& Zimmer, 1996). As a result, the high stocking rate and the best animal performance in the rainy season are reduced during the dry season (Euclides, Montagner, Barbosa, Valle, \& Nantes, 2016).

To circumvent or minimize the problems resulting from low forage production throughout the dry season, stockpiling pasture is an appropriate management strategy (Santos et al., 2009a; Silva et al., 2016). It consists of excluding a pasture area from grazing in late summer or early autumn. Thus, the forage will accumulate in the pasture and be used for grazing only in the period of forage scarcity (dry season).

The most suitable forage grasses for pasture stockpile are those with low stem growth and good green leaf retention in winter, which results in pasture with lower reduction of nutritional value during the stockpiling period (Euclides, Flores, Medeiros, \& Oliveira, 2007). Most of the grasses of the genus Urochloa, such as U. brizantha cv. Marandu (Marandu palisade grass), stand out amongst the grasses with these characteristics.

Although its usage is more frequent in high rainfall periods, nitrogen fertilization can increase forage production during the stockpiling period (Santos \& Fonseca, 2016). The application of nitrogen at the beginning of the stockpiling period increases the forage mass and stimulates tillering, as long as the stockpiling period is not too long (Santos et al. 2009b).

In addition to nitrogen fertilization, variation in the average height of the pasture at the beginning of the stockpiling period also has an effect on the characteristics of the deferred pasture (Santos et al., 2009a; Vilela et al., 2012). The higher initial height of the pasture can result in a deferred pasture with a larger forage mass, yet with worse morphological composition. Lowering the pasture early in the stockpiling period has been recommended in order to avoid these negative effects (Vilela et al., 2012). However, the lower height of the pasture at the beginning of the stockpile can reduce forage production. In this context, nitrogen 
fertilization could be used in order to increase forage production in the lowered pasture through more vigorous regrowth (Sousa et al., 2012), especially of younger tillers, which has a higher growth rate ( Paiva et al., 2011; Barbosa et al., 2012; Alves et al., 2019).

Understanding the possible interactions and benefits of nitrogen fertilization, along with the variation in the height of the pasture at the beginning of the stockpile can result in management recommendations, which can provide stockpiled pasture with better characteristics for animal production during the dry season. This study aims to evaluate how height and the nitrogen dose at the beginning of the stockpile period affect the structural characteristics of stockpiled Marandu palisade grass.

\section{Material and methods}

The experiment was carried out in a pasture area of Urochloaa brizantha cv. Marandu (Marandu palisade grass) established in 2000. Before the start of evaluation in the experimental area, the Marandu grass pasture was managed in continuous stocking with cattle.

The pasture was located at the Capim-branco Experimental Farm, at the Federal University of Uberlândia, in the City of Uberlândia, Minas Gerais, Brazil. The geographic coordinates of the site are $18^{\circ} 30^{\prime}$ south latitude, $47^{\circ} 50^{\prime}$ west longitude, and $863 \mathrm{~m}$ altitude. According to the Köppen classification, the climate is Aw, tropical savanna, with welldefined rainy (October to March) and dry (April to September) seasons (Alvares, Stape, Sentelhas, Gonçalves, \& Sparovek, 2013). The average annual temperature and precipitation are $22.3^{\circ} \mathrm{C}$ and $1,584 \mathrm{~mm}$, respectively. Information regarding climatic conditions during the experiment was recorded at the Meteorological Station located approximately $200 \mathrm{~m}$ from the experimental area (Figure 1). 
Figure 1 - Monthly averages of minimum, mean and maximum air temperatures, total monthly rainfall, and total monthly evapotranspiration from January to July 2012.

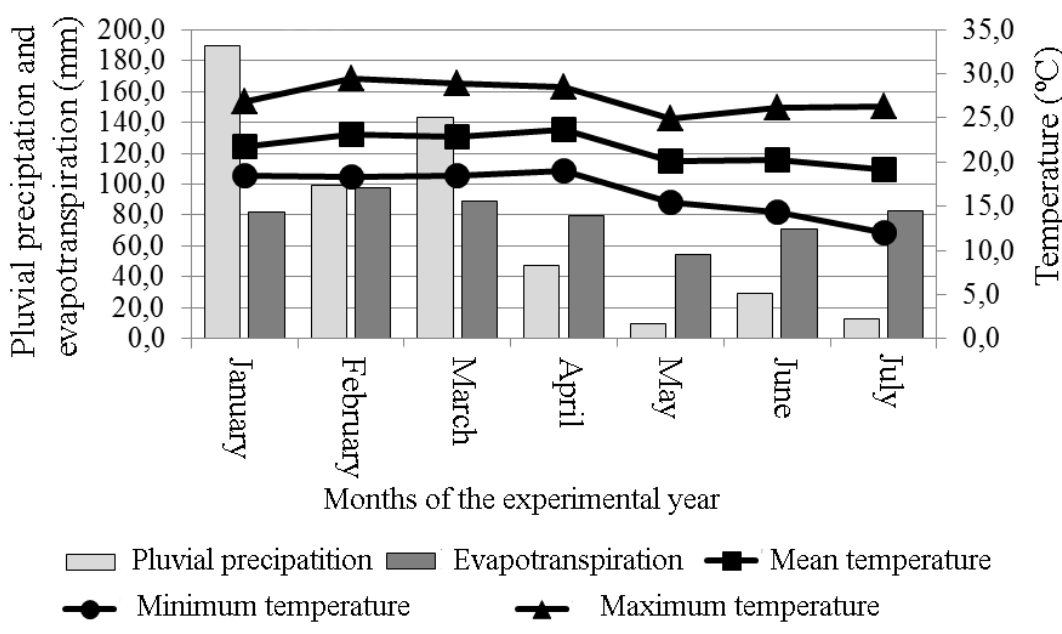

Before implementing the experiment, soil samples were taken to analyze the level of fertility, in the $0-20 \mathrm{~cm}$ layer, with the following results: $\mathrm{H}_{2} \mathrm{O}$ pH: 6.1; P: 2.5 (Mehlich-1) and $\mathrm{K}: 94 \mathrm{mg} \mathrm{dm}{ }^{-3} ; \mathrm{Ca}^{2+}: 3.1 ; \mathrm{Mg}^{2+}: 1.3 ; \mathrm{Al}^{3+}$ : $0,0 \mathrm{cmol}_{\mathrm{c}} \mathrm{dm}^{-3}\left(\mathrm{KCl} 1 \mathrm{~mol} \mathrm{~L}^{-1}\right)$. According to this result, applications of phosphate (50 kg ha-1 of $\mathrm{P}_{2} \mathrm{O}_{5}$ in the form of simple superphosphate) and potassium (70 kg ha-1 of $\mathrm{K}_{2} \mathrm{O}$ in the form of potassium chloride) fertilizers were carried out in February 2012.

Two canopy heights (15 and $30 \mathrm{~cm}$ ) and four nitrogen doses $(0,40,80$, and $120 \mathrm{~kg} \mathrm{ha}^{-1}$ of $\mathrm{N}$ ) were evaluated at the beginning of the stockpiling period. A completely randomized design $2 \times 4$ factorial was used with three replications. The $6 \mathrm{~m}^{2}(2 \mathrm{~m} \times 3 \mathrm{~m})$ plots were allocated to the pasture area after the removal of the animals from the pasture on March 15th, 2012. On that date, the Marandu grass pasture had an average height of $30 \mathrm{~cm}$. After randomizing treatments in the plots, 15 and $30-\mathrm{cm}$ heights were established using pruning shears. The nitrogen fertilizer doses were applied after adjusting the heights. Fertilizer urea was used as a nitrogen source, in a single dose and in the late afternoon.

The plots remained stockpiled from March 15th, 2012 to June 22nd, 2012 (99 days). At the end of this period, all assessments were carried out 
in the useful area $\left(3.75 \mathrm{~m}^{2}\right)$ of each plot. Basal tiller population density was determined by taking two samples per plot, at points that represented the average canopy height. Basal tillers were considered to be those originating from basal buds, located close to or at the level of the soil surface. The tillers were harvested at ground level and in an area bounded by a 0.25 x $0.50 \mathrm{~m}$ metal frame. Afterward, they were packed in plastic bags and quantified in the laboratory.

To determine the forage mass, all tillers contained within a $0.50 \mathrm{x}$ $0.50 \mathrm{~m}$ frame were harvested, also at ground level, in two representative areas of the average canopy height in each plot. The samples were packed in a plastic bag and weighed in the laboratory. Two subsamples were taken from each sample, one of which was weighed, packed in a paper bag and placed in an oven with forced air ventilation, at $65{ }^{\circ} \mathrm{C}$, for 72 hours. The other subsample was separated into a live leaf blade (LLF) and a dead leaf blade (DLB), live stem (LE) and dead stem (DE). The green inflorescence and leaf sheath were incorporated into the LE fraction. The part of the leaf blade that did not show signs of senescence (green colored organ) was also incorporated into the LLF fraction. The parts of the stem and the senescent leaf blade (with yellowing and, or, necrotizing) were incorporated into the DE and DLB fraction, respectively. After separation, the components were dried in a forced air oven at $65{ }^{\circ} \mathrm{C}$ for 72 hours and weighed.

To determine the leaf area index, 50 leaf blades were collected in each plot. These had a small part of their ends (apex and base) cut and discarded, in order to obtain an approximately rectangular leaf blade segment. The width and length of each segment were measured and, using the product of these dimensions, the leaf area was obtained. These segments were placed in a forced ventilation oven at $65{ }^{\circ} \mathrm{C}$ for 72 hours and then weighed. The specific leaf area $\left(\mathrm{cm}^{2} \mathrm{~g}-1\right.$ leaf blade) was calculated by dividing the leaf area by weight. The canopy leaf area index was calculated by multiplying the specific leaf area by the live leaf blade mass present in the deferred canopy. 
The height of the forage canopy was determined with a ruler and corresponded to the distance between the part of the plant located higher in the canopy and the ground level at five points of the plot. All efforts were made so as not to cause disturbance in the pasture. The height of the extended plant was obtained at the same points and, after the measurement of the canopy height, by extending the grass tillers in the vertical direction and noting the greatest distance from the ground level to the top of the tillers. The plant falling index was calculated by dividing the height of the extended plant by the height of the plant (Santos et al., 2009c). Due to the difference between the height of the pasture at the beginning and the end of the stockpiling period, height variation was measured.

The analysis of the experimental data was performed using the System for Statistical Analysis - SAEG, version 8.1 (Federal University of Viçosa, 2003). All statistical analyses were carried out at the level of $10 \%$ probability of occurrence of type I error. The data were previously tested to ensure that they met the basic prerogatives for analysis of variance. Data normality was measured with the Kolmogorov-Smirnov test, while the Bartlett test was used to investigate data homogeneity. For the nitrogen dose factor (quantitative factor), regression analyses were performed with selection of models that best fit the data within each height of the pasture. The largest response surface model for the averages of the nitrogen dose factor was as follows:

$$
\mathrm{Yi}=\mathrm{B0}+81 \mathrm{Ni}+82 \mathrm{Ni}^{2}+\mathrm{ei}
$$

Where: $\mathrm{Yi}=$ response variable; $\mathrm{Ni}=$ nitrogen dose; $\mathrm{B0}, \mathrm{B1}, \mathrm{B2}=$ parameters to be estimated; ei = experimental error. The degree of adjustment of the models was assessed by the coefficient of determination and the significance of the regression coefficients, tested by the corrected $t$ test based on the residuals of the analysis of variance. For height (qualitative factor), a Tukey test was applied across the four doses of nitrogen. 


\section{Results and discussion}

Increases were found in the height of the canopy and the extended plant $(\mathrm{P} \leq 0,10)$ in response to the application of $\mathrm{N}$ and to the highest height of the canopy at the beginning of the stockpiling period. However, the falling index of the plant did not vary with the factors under scrutiny (Table 1).

Table 1 - Heights and falling index in Marandu grass canopies managed with variable heights and nitrogen doses at the beginning of the stockpiling period

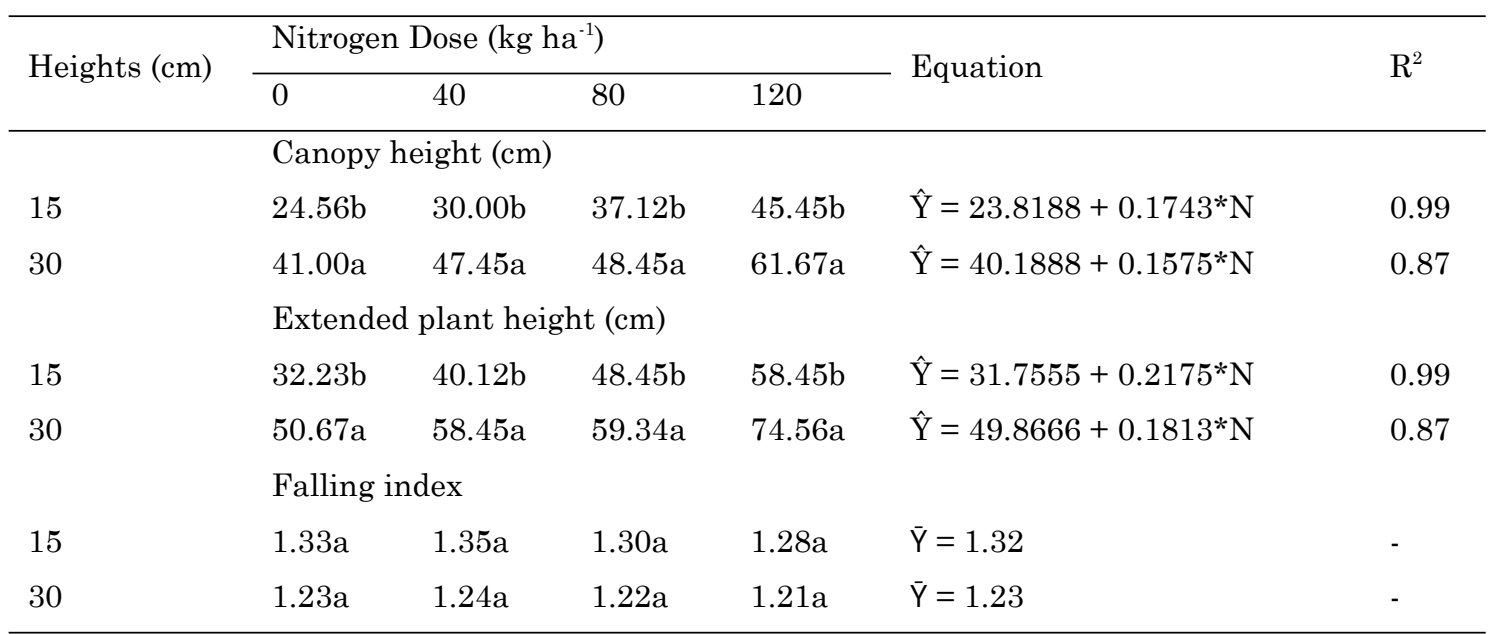

For each variable, means followed by the same letter in the column do not differ $(\mathrm{P}>0,10)$ according to Tukey test. * Significant to $t$ test $(\mathrm{P} \leq 0,10)$.

In stockpiled pastures, the final height is result the initial height plus the height variation in the stockpiling period. Thus, the highest initial height $(30 \mathrm{~cm})$ and the greatest height variation during stockpiling with $\mathrm{N}$ application (Table 2) justify the canopy and extended plant heights (Table 1).

With the growth of tiller, the plants' potential to falling also grows. According to the classification proposed by Santos (2007), there was no significant falling of plants in the stockpiled Marandu grass canopies. The falling index values were low probably because there was no grazing, since animal movement increases the falling of plants, especially in pastures with greater height. In this context, it can be inferred that pastures with the highest initial height and fertilized with $\mathrm{N}$ tend to be more susceptible to 
falling when grazing, as they have greater extended plant height, even with a low falling index (Table 1).

The variation in the pasture height during the stockpiling period was not influenced $(\mathrm{P}>0.10)$ by the two initial heights $(15$ or $30 \mathrm{~cm})$. However, nitrogen doses influenced this characteristic $(\mathrm{P}<0.10)$ linearly and positively (Table 2).

Table 2 - Canopy height variation of Marandu grass, in cm, as a function of nitrogen doses applied at two heights at the beginning of the stockpiling period

\begin{tabular}{|c|c|c|c|c|c|c|}
\hline \multirow{2}{*}{ Height $(\mathrm{cm})$} & \multicolumn{4}{|c|}{ Nitrogen Dose $\left(\mathrm{kg} \mathrm{ha}^{-1}\right)$} & \multirow{2}{*}{ Equation } & \multirow{2}{*}{$\mathrm{R}^{2}$} \\
\hline & 0 & 40 & 80 & 120 & & \\
\hline 15 & $9.57 \mathrm{a}$ & $15.00 \mathrm{a}$ & $22.12 \mathrm{a}$ & $30.45 a$ & $\hat{\mathrm{Y}}=8.8188+0.1743^{*} \mathrm{~N}$ & 0.99 \\
\hline 30 & $11.00 \mathrm{a}$ & $17.45 \mathrm{a}$ & $18.45 \mathrm{a}$ & $31.67 \mathrm{a}$ & $\hat{\mathrm{Y}}=10.1888+0.1575 * \mathrm{~N}$ & 0.87 \\
\hline
\end{tabular}

For each variable, means followed by the same letter in the column do not differ $(\mathrm{P}>0.10)$ according to the Tukey test. * Significant according to $t$ test $(\mathrm{P} \leq 0.10)$.

The highest stockpiled pasture was expected to show greater growth and height variation during the stockpiling period, as it probably started to grow with a higher leaf area index (LAI), an essential condition for light interception through the canopy, high photosynthesis rate and, consequently, greater pasture growth (Paula et al., 2012). However, the high pasture possibly started its development based on longer and older tillers, which did not have their apical meristem removed at the beginning of the stockpiling period. These old tillers, in general, have low leaf and stem growth rates (Paiva et al., 2011). In fact, in evaluating the effect of tiller age on the morphogenic and structural characteristics of Tanzania grass (Megathyrsus maximus) submitted to the rotating grazing strategy, Barbosa et al. (2012) found reduced growth rate of the tillers in function of their increased age. In contrast, in a stockpiled pasture with lower initial height, the leaf area index (LAI) is probably low, which can limit light interception, photosynthesis, and pasture growth. However, the lowering of the pasture promotes a higher incidence of light at the plant base, which stimulates the 
growth of younger vegetative tillers with higher rates of appearance and leaf growth (Paiva et al., 2011). Thus, the non-effect of the initial pasture height on the height variation during the stockpiling period can be justified by compensation between the leaf area index (LAI) and the age of tillers, which were different in 15 and $30-\mathrm{cm}$ pastures.

Nitrogen $(\mathrm{N})$ promoted a linear increase in the height variation of the pasture in the stockpiling period (Table 2). This nutrient has been proven to stimulate the photosynthesis of the pasture, both because it is a constituent of fundamental biomolecules such as proteins and chlorophylls and because it is required in greater quantities in plants as compared to other mineral nutrients (Santos \& Fonseca, 2016). Thus, when in high availability, N results in a significant increase in the growth of forage grass because of the changes it promotes in the plant's morphogenic characteristics (appearance, elongation, and leaf life) (Martuscello et al., 2005; Fagundes et al., 2006).

The number of basal tillers was higher in the 15-cm stockpiled pasture compared to the $30-\mathrm{cm}$ one only when the highest dose of $\mathrm{N}$ was used (Table 3). Possibly, the higher incidence of light at the base of $15-\mathrm{cm}$ plants stimulated the development of buds in new tillers, especially when the pasture was fertilized with a high dose of $\mathrm{N}$. This response pattern was also found by Silva et al. (2015), who worked with Urochloa decumbens cv. Basilisk and found that the 10-cm deferred canopy had a greater number of tillers compared to those with 20 and $30 \mathrm{~cm}$.

Table 3 - Basal tiller number $\mathrm{m}^{-2}$ in Marandu grass canopies managed with varying heights and nitrogen doses at the beginning of the stockpiling period

\begin{tabular}{lllllll}
\hline \multirow{2}{*}{ Height $(\mathrm{cm})$} & \multicolumn{3}{l}{ Nitrogen Dose $\left(\mathrm{kg} \mathrm{ha}^{-1}\right)$} & Equation & $\mathrm{R}^{2}$ \\
\cline { 2 - 5 } & 0 & 40 & 80 & 120 & 0.76 \\
\hline 15 & $613 \mathrm{a}$ & $689 \mathrm{a}$ & $662 \mathrm{a}$ & $783 \mathrm{a}$ & $\hat{\mathrm{Y}}=614.7+1.2008^{*} \mathrm{~N}$ & 0.99 \\
30 & $619 \mathrm{a}$ & $634 \mathrm{a}$ & $596 \mathrm{a}$ & $535 \mathrm{~b}$ & $\hat{\mathrm{Y}}=620.12+0.7071 * \mathrm{~N}-0.0119^{*} \mathrm{~N}^{2}$ & \\
\hline
\end{tabular}

For each variable, means followed by the same letter in the column do not differ $(\mathrm{P}>0.10)$ by Tukey test. * Significant by t test $(\mathrm{P} \leq 0.10)$. 
$\mathrm{N}$ linearly increased the number of basal tillers in the $15-\mathrm{cm}$ deferred pasture. However, the response of $\mathrm{N}$ was quadratic for the $30-\mathrm{cm}$ deferred pasture (Table 3). It is possible that, in the low pasture $(15 \mathrm{~cm})$ with lower leaf area index (LAI), nitrogen stimulated the linear development of basal buds in tiller, because the interior of the canopy was little shaded. However, in initially high pasture $(30 \mathrm{~cm})$, there were probably a greater leaf area index (LAI) and shading inside the canopy, which may have accentuated during the stockpiling period, especially with the application of higher doses of $\mathrm{N}$. Thus, lower doses of $\mathrm{N}$ stimulated tillering, while higher doses of $\mathrm{N}$ inhibited it, because of the high shading at the plant base. A similar response pattern was observed by Santos et al. (2009) with deferred canopies of $U$. decumbens cv. Basilisk in the region of Viçosa, Minas Gerais, Brazil.

Leaf area index (LAI) values did not vary with the initial canopy height (Table 4). The highest deferred canopy was expected to present a higher LAI at the end of the stockpiling period, due to the positive association between canopy height and LAI (Paula et al., 2012). As previously discussed, it is possible that in the low pasture the initial LAI had been reduced during its lowering, thereby stimulating the growth of young tillers, which produce more leaves. Otherwise, in the high pasture with the highest initial LAI, its leaf growth was probably lower due to the old age of the tillers, with several of them entering in the reproductive phase. Furthermore, in high pasture, the senescence of the leaves is also greater (Paula et al., 2012), which may have contributed to stabilizing the leaf area index (LAI).

Table 4 - Leaf area index in Marandu grass pastures managed with varying heights and nitrogen doses at the beginning of the stockpiling period

\begin{tabular}{ccccccc}
\hline \multirow{2}{*}{$\begin{array}{c}\text { Height } \\
(\mathrm{cm})\end{array}$} & \multicolumn{4}{c}{ Nitrogen Dose $\left(\mathrm{kg} \mathrm{ha}^{-1}\right)$} & Equation & \multirow{2}{*}{$\mathrm{R}^{2}$} \\
\cline { 2 - 5 } & 0 & 40 & 80 & 120 & $\hat{\mathrm{Y}}=2.3357+0.0543^{*} \mathrm{~N}-$ & 0.9
\end{tabular}


30

$\begin{array}{cccc}\mathrm{a} & \mathrm{a} & \mathrm{a} & \mathrm{a} \\ 3.16 & 3.59 & 4.16 & 4.54\end{array}$

$0.0003 * \mathrm{~N}^{2}$

9

$\hat{\mathrm{Y}}=3.1636+0.0117^{*} \mathrm{~N}$

For each variable, means followed by the same letter in the column do not differ $(\mathrm{P}>0.10)$ according to the Tukey test. ${ }^{*}$ Significant according to t test $(\mathrm{P} \leq 0.10)$.

The leaf area index (LAI) increased with the application of $\mathrm{N}$ in the stockpiled canopies (Table 3) because of the $\mathrm{N}$ stimulus on the number of tillers (Table 3). $\mathrm{N}$ also leads to a higher growth rate in individual tillers (Martuscello et al. 2005; Fagundes et al., 2006), which also contributes to increasing the LAI.

The increase in the $\mathrm{N}$ dose at the beginning of the stockpiling resulted in positive and quadratic effects on the forage mass only in the $15-\mathrm{cm}$ deferred pasture (Table 5). In this condition, the dose of $\mathrm{N}$ resulted in a greater forage mass at the end of the stockpiling period (maximum point) when it was $105.35 \mathrm{k} \mathrm{ha}^{-1}$ of $\mathrm{N}$. When $\mathrm{N}$ was not applied and when $80 \mathrm{~kg} \mathrm{ha}^{-1}$ of $\mathrm{N}$ was used, the $30-\mathrm{cm}$ deferred canopies presented $(\mathrm{P}<0.10)$ greater forage mass than the $15-\mathrm{cm}$ ones (Table 5). This was due to the greater forage mass already existing at the beginning of the stockpiling period in the highest canopies.

Table 5 - Forage mass, in $\mathrm{kg} \mathrm{ha}^{-1} \mathrm{DM}$, of Marandu grass canopies managed with varying heights and nitrogen doses at the beginning of the stockpiling period

\begin{tabular}{|c|c|c|c|c|c|c|}
\hline \multirow{2}{*}{$\begin{array}{l}\text { Height } \\
(\mathrm{cm})\end{array}$} & \multicolumn{4}{|c|}{ Nitrogen Dose $\left(\mathrm{kg} \mathrm{ha}^{-1}\right)$} & \multirow{2}{*}{ Equation } & \multirow{2}{*}{$\mathrm{R}^{2}$} \\
\hline & 0 & 40 & 80 & 120 & & \\
\hline 15 & $4730 \mathrm{~b}$ & $6312 \mathrm{a}$ & $7008 b$ & $7173 a$ & $\begin{array}{l}\hat{\mathrm{Y}}=4747.6+46.623^{*} \mathrm{~N}- \\
0.2213^{*} \mathrm{~N}^{2}\end{array}$ & 0.99 \\
\hline 30 & $7651 \mathrm{a}$ & $7485 a$ & $9146 a$ & $8032 \mathrm{a}$ & $\bar{Y}=8078$ & - \\
\hline
\end{tabular}

For each variable, means followed by the same letter in the column do not differ $(\mathrm{P}>0.10)$ according to the Tukey test. * Significant according to $t$ test $(\mathrm{P} \leq 0.10)$.

The stockpile of the canopy with a lower height and a higher dose of $\mathrm{N}$ enabled a similar forage mass $\left(7,173 \mathrm{~kg} \mathrm{ha}^{-1}\right.$ of DM) compared to the stockpiled 
canopy with a higher height and without application of $\mathrm{N}\left(7,651 \mathrm{~kg} \mathrm{ha}^{-1}\right.$ of DM). This compensatory effect provides cattle ranchers with greater flexibility in the management of stockpiled pasture, which is another benefit of using nitrogen fertilizers in pastures (Santos \& Fonseca, 2016).

Regarding the morphological components in the forage mass of the deferred canopies, the percentage of dead leaf increased $(\mathrm{P}<0,10)$ with the application of $\mathrm{N}$ in the deferred pastures (Table 6). Probably, the greater development of the fertilized pasture resulted in high shading inside the canopy. As a result, leaf blades became more shaded, increasing senescence (Paula et al., 2012). This same process may have been responsible for the higher percentage of dead leaf blade in 30-cm stockpiled canopies as compared to the $15-\mathrm{cm}$ ones when applying doses of 0 and $40 \mathrm{~kg} \mathrm{ha}^{-1}$ of $\mathrm{N}$.

The percentage of live leaf was higher in the 15-cm deferred canopy (compared to the $30-\mathrm{cm}$ ones) when it was fertilized with 40 and $80 \mathrm{~kg} \mathrm{ha}^{-1}$ of $\mathrm{N}$ (Table 6). Possibly, the high shading in the high canopies explains these results, as previously discussed. However, in the 15-cm stockpiled pasture, the percentage of live leaf blade increased linearly with the application of $\mathrm{N}$ (Table 6). A possible explanation for this result may be the effect of $\mathrm{N}$ on increasing the life span of leaves of forage grass (Garcez Neto et al., 2002). Thus, it is possible that young leaves, which appeared during the stockpiling period, remained alive for a longer time, which increased their percentage in the stockpiled pasture. However, those older leaves, which already existed at the beginning of the stockpiling period, may have become senescent more quickly with nitrogen fertilization.

Table 6 - Percentage of morphological components in the forage mass in Marandu grass canopies managed with varying heights and nitrogen doses at the beginning of the stockpiling period

\begin{tabular}{|c|c|c|c|}
\hline \multirow{2}{*}{ Height (cm) } & Nitrogen Dose $\left(\mathrm{kg} \mathrm{ha}^{-1}\right)$ & \multirow{2}{*}{ Equation } & \multirow{2}{*}{$\mathrm{R}^{2}$} \\
\hline & 80 & & \\
\hline
\end{tabular}




\begin{tabular}{|c|c|c|c|c|c|c|}
\hline 15 & $26.5 \mathrm{a}$ & $31.4 \mathrm{a}$ & $33.5 \mathrm{a}$ & $33.5 \mathrm{a}$ & $\hat{\mathrm{Y}}=27.7448+0.0578^{*} \mathrm{~N}$ & 0.82 \\
\hline \multirow[t]{2}{*}{30} & $23.6 \mathrm{a}$ & $26.3 \mathrm{~b}$ & $24.0 \mathrm{~b}$ & $28.9 \mathrm{a}$ & $\bar{Y}=25.7$ & - \\
\hline & \multicolumn{6}{|c|}{ Dead leaf blade (\%) } \\
\hline 15 & $15.7 \mathrm{~b}$ & $28.8 \mathrm{~b}$ & $27.6 \mathrm{a}$ & $30.7 \mathrm{a}$ & $\hat{\mathrm{Y}}=20.5411+0.0946^{*} \mathrm{~N}$ & 0.71 \\
\hline \multirow[t]{2}{*}{30} & $29.7 \mathrm{a}$ & $31.8 \mathrm{a}$ & $29.3 \mathrm{a}$ & $36.7 \mathrm{a}$ & $\hat{\mathrm{Y}}=27.8526+0.0594 * \mathrm{~N}$ & 0.62 \\
\hline & \multicolumn{6}{|c|}{ Live stem (\%) } \\
\hline 15 & $20.8 \mathrm{a}$ & $19.3 \mathrm{a}$ & $17.6 \mathrm{a}$ & $16.9 \mathrm{a}$ & $\hat{\mathrm{Y}}=20.6458-0.0332 * \mathrm{~N}$ & 0.97 \\
\hline \multirow[t]{2}{*}{30} & $19.8 \mathrm{a}$ & $17.8 \mathrm{a}$ & $15.0 \mathrm{a}$ & $17.4 \mathrm{a}$ & $\bar{Y}=17.5$ & - \\
\hline & \multicolumn{6}{|c|}{ Dead stem (\%) } \\
\hline 15 & $34.1 \mathrm{a}$ & $20.5 \mathrm{a}$ & $21.3 \mathrm{a}$ & $17.1 \mathrm{a}$ & $\hat{\mathrm{Y}}=30.4403-0.1125^{*} \mathrm{~N}$ & 0.68 \\
\hline 30 & $28.7 \mathrm{a}$ & $23.5 \mathrm{a}$ & $29.9 \mathrm{a}$ & $18.8 \mathrm{a}$ & $\bar{Y}=24.8$ & - \\
\hline
\end{tabular}

For each variable, means followed by the same letter in the column do not differ $(\mathrm{P}>0.10)$ according to the Tukey test. * Significant according to t test $(\mathrm{P} \leq 0.10)$.

The percentages of live stem and dead stem $(\mathrm{P}>0,10)$ did not vary with the initial height of the canopy (Table 6). The long stockpiling period (99 days) may have canceled out the effects of the initial canopy height on these characteristics. However, nitrogen fertilization reduced the percentage of live and dead stem, contributing to a more suitable forage canopy structure for grazing.

\section{Conclusions}

Greater forage mass can be obtained in the dry season when Urochloa brizantha cv. Marandu is stockpiled either at $15 \mathrm{~cm}$ height and fertilized with approximately $100 \mathrm{~kg} \mathrm{ha}^{-1}$ of $\mathrm{N}$ or at $30 \mathrm{~cm}$ without nitrogen fertilization. Nitrogen fertilization improves the structural characteristics of $U$. brizantha cv. Marandu in the winter when associated with reduced canopy height at the beginning of the stockpiling period. 


\title{
Acknowledgements
}

The authors are thankful to the members of the Federal University of Uberlândia's TESTHFOR (Group of Hypothesis Testing in Forage Culture) for their contributions to this research work.

\section{Estrutura do capim-marandu diferido com alturas e doses de nitrogênio crescentes}

\begin{abstract}
Resumo: O objetivo deste trabalho foi avaliar os efeitos da altura (15 e 30 $\mathrm{cm}$ ) e da dose de nitrogênio (N, 0, 40, 80 e $120 \mathrm{~kg} \mathrm{ha}^{-1}$ ) no início do período de diferimento sobre as características estruturais da Urochloa brizantha cv. Marandu (capim-marandu) durante o inverno. O índice de tombamento da planta não variou com os fatores estudados $(\mathrm{P}>0,10)$. $\mathrm{O}$ número de perfilho basal foi maior $(\mathrm{P} \leq 0,10)$ no dossel diferido $\mathrm{com} 15 \mathrm{~cm}$ do que naquele com $30 \mathrm{~cm}$ apenas quando a maior dose de $\mathrm{N}$ foi utilizada. Nas condições em que $\mathrm{N}$ não foi aplicado e quando $80 \mathrm{~kg} \mathrm{ha}^{-1}$ de $\mathrm{N}$ foi empregado, os dosséis diferidos com $30 \mathrm{~cm}$ apresentaram maior $(\mathrm{P} \leq 0,10)$ massa de forragem do que aqueles com $15 \mathrm{~cm}$. Associada à redução da altura do dossel no início do período de diferimento, a adubação nitrogenada melhora a composição morfológica do capim-marandu. Para maximizar a massa de forragem na época seca do ano, os dosséis de capimmarandu podem, no início do período de diferimento, ser diferidos (i) com $15 \mathrm{~cm}$ e adubados com cerca de $100 \mathrm{~kg} \mathrm{ha}^{-1}$ de $\mathrm{N}$ ou (ii) com $30 \mathrm{~cm}$ e sem adubação nitrogenada.

Palavras-chave: Brachiaria brizantha, composição morfológica, índice de tombamento, massa de forragem, Urochloa brizantha.
\end{abstract}

\section{References}

ALVARES, C. A.; STAPE, J. L.; SENTELHAS, P. C.; GONÇALVES, J. L. M.; SPAROVEK, G. Köppen's climate classification map for Brazil. Meteorologische Zeitschrift, v. 22, n. 6, p. 711-728, December 2013. Disponível em: < https://doi.org/ 10.1127/0941-2948/2013/0507 >. Acesso em: 20 maio 2020. 
ALVES, L. C.; SANTOS, M. E. R.; PEREIRA, L. E. T.; CARVALHO, A. N.; ROCHA, G. O.; CARVALHO, B. H. R.; VASCONCELOS, K. A.; AVILA, A. B. Morphogenesis of age groups of Marandu palisade grass tillers deferred and fertilised with nitrogen. SEMINA. CIÊNCIAS AGRÁRIAS, v. 40, n. 6, p. 2683, 2019. Disponível em: < https://doi.org/10.5433/1679-0359.2019v40n6p2683 >. Acesso em: 20 maio 2020 .

BARBOSA, R. A.; NASCIMENTO JUNIOR, D. do; VILELA, H. H.; SOUSA, B. M. L.; DA SILVA, S. C.; EUCLIDES, V. P. B.; SILVEIRA, M. C. T. Morphogenetic and structural characteristics of guinea grass tillers at different ages under intermittent stocking. Revista Brasileira de Zootecnia, v. 41, n. 7, p. 1583-1588, July 2012. Disponível em: <https://doi.org/10.1590/S1516-35982012000700005>. Acesso em: 20 maio 2020.

EUCliDES, V. P. B.; FLORES, R. S.; MEDEIROS, R. N. de; OLIVEIRA, M. P. Diferimento de pastos de braquiária cultivares Basilisk e Marandu, na região do Cerrado. Pesquisa Agropecuária Brasileira, v. 42, n. 2, p. 273-280, February 2007. Disponível em: < https://doi.org/10.1590/S0100-204X2007000200017 >. Acesso em: 20 maio 2020.

EUClides, V. P. B.; MONTAGNER, D. B.; BARBOSA, R. A.; VAlLE, C. B. DO; NANTES, N. N. (2016). Animal performance and sward characteristics of two cultivars of Brachiaria brizantha (BRS Paiaguás and BRS Piatã). Revista Brasileira de Zootecnia, v. 45, n. 3, p. 85-92, March 2016. Disponível em: < https://doi.org/10.1590/S1806-92902016000300001 >. Acesso em: 20 maio 2020.

FAGUNDES, J. L.; FONSECA, D. M.; MISTURA, C.; MORAIS, R. V.; VITOR, C. M. T.; GOMIDE, J. A.; NASCIMENTO JÚNIOR, D.; CASAGRANDE, D. R.; COSTA, L. T. Características morfogênicas e estruturais do capim-braquiária em pastagem adubada com nitrogênio avaliadas nas quatro estações do ano. Revista Brasileira de Zootecnia, v. 35, n. 1, p. 21-29, 2006. Disponível em: < https://doi.org/ 10.1590/S1516-35982006000100003 >. Acesso em: 20 maio 2020. 
GARCEZ NETO, A. F.; NASCIMENTO JR.; D., REGAZZI, A. J.; FONSECA, D. M.; MOSQUIM, P. R.; GOBBI, K. F. Respostas morfogênicas e estruturais de Panicum maximum cv. Mombaça sob diferentes níveis de adubação nitrogenada e alturas de corte. Revista Brasileira de Zootecnia, v. 31, n. 5, p.1890-1900, 2002. Disponível em: <https://doi.org/10.1590/S1516-35982002000800004>. Acesso em: 20 maio 2020 .

MARTUSCELLO, J. A.; FONSECA, D. M.; NASCIMENTO JÚNIOR, D.; S ANTOS, P. M.; RIBEIRO JUNIOR, J. I.; CUNHA, D. N. F. V.; MOREIRA, L. M. Características morfogênicas e estruturais do capim xaraés submetido à adubação nitrogenada e desfolhação. Revista Brasileira de Zootecnia, v. 34, n. 5, p. 14751482, 2005. Disponível em: <http://dx.doi.org/10.1590/S1516-35982005000500007>. Acesso em: 20 maio 2020.

PAIVA, A. J.; SIlVA, S. C.; PEREIRA, L. E. T.; CAMINHA, F. O.; PEREIRA, P. M.; GUARDA, V. D. Morphogenesis on age categories of tillers in marandu Palisadegrass. Scientia Agricola, v. 68, n. 6, p. 626-631, 2011. Disponível em: < https://doi.org/10.1590/S0103-90162011000600003 >. Acesso em: 20 maio 2020.

PAUlA, C. C. L. de.; EUClIDES, V. P. B.; LEMPP, B.; BARBOSA, R. A.; MONTAGNER, D. B.; CARLOTO, M. N. Acúmulo de forragem, características morfogênicas e estruturais do capim-marandu sob alturas de pastejo. Ciência Rural, v. 42, n. 11, p. 2059-2065, 2012. Disponível em: < https://doi.org/10.1590/S0103$\underline{84782012005000084}$ >. Acesso em: 20 maio 2020.

PIZARRO, E. A.; VALLE, C. B.; SÉLLER-GREIN, G.; SCHULTZEKRAFT, R.; ZIMMER, A. H. (1996). Regional experience with Brachiaria: Tropical Americasavannas. In: MILES, J. W.; MAASS, B. L.; VALLE, C. B. (Ed.). Brachiaria: biology, agronomy and improvement. Calli: CIAT; Campo Grande: EmbrapaCNPGC, 225-246.

SANTOS, M. E. R. (2007). Características da forragem e produção de bovinos em pastagens de capim-braquiária diferidas. Universidade Federal de Viçosa. 
Disponível em: <http://locus.ufv.br/handle/123456789/5857>. Acesso em: 20 maio 2020.

SANTOS, M. E. R.; FONSECA, D. M.; EUCLIDES, V. P. B.; RIBEIRO JUNIOR, J. I.; NASCIMENTO JUNIOR, D.; MOREIRA, L. M. Produção de bovinos em pastagens de capim-braquiária diferidas. Revista Brasileira de Zootecnia, v. 38, n. 4, p. 635-642, 2009a. Disponível em: <https://doi.org/10.1590/S151635982009000400007>. Acesso em: 20 maio 2020.

SANTOS, M. E. R.; FONSECA, D. M.; BALBINO, E. M.; MONNERAT, J. P.; SILVA, S. P. Capim-braquiária diferido e adubado com nitrogênio: produção e características da forragem. Revista Brasileira de Zootecnia, v. 38, n. 4, p. 650-656,

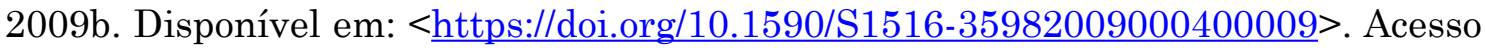
em: 20 maio 2020 .

SANTOS, M. E. R.; FONSECA, D. M.; EUCLIDES, V. P. B.; NASCIMENTO J. R. D.; QUEIROZ, A. C.; RIBEIRO J. R. J. I. Características estruturais e índice de tombamento de Brachiaria decumbens cv. Basilisk em pastagens diferidas. Revista Brasileira de Zootecnia, v. 38, n. 4, p. 626-634, 2009c. Disponível em: <https://doi.org/10.1590/S1516-35982009000400006>. Acesso em: 20 maio 2020.

SANTOS, M. E. R.; FONSECA, D. M.; BALBINO, E. M.; MONNERAT, J. P.; SILVA, S. P. Caracterização dos perfilhos em pastos de capim-braquiária diferidos e adubados com nitrogênio. Revista Brasileira de Zootecnia, v. 38, n. 4, p. 643-649, 2009d. Disponível em: <https://doi.org/10.1590/S1516-35982009000400008>. Acesso em: 20 maio 2020.

SANTOS, M. E. R.; FONSECA, D. M. (2016). Adubação de pastagens em sistemas de produção animal. Viçosa: Ed. UFV.

SILVA, A. A. S.; FONSECA, D. M.; SANTOS, M. E. R.; SOUSA, B. M. L.; GOMES, V. M.; CANTARUTTI, R. B. Initial height and nitrogen fertilization on deferred 
signal grass. Bioscience Journal, v. 31, n. 6, p. 1671-1681, 2015. Disponível em: <https://doi.org/10.14393/BJ-v31n6a2015-26277>. Acesso em: 20 maio 2020.

SILVA, C. S.; MONTAGNER, D. B.; EUCLIDES, V. P. B.; QUEIROZ, C. DE A.; ANDRADE, R. A. S. Steer performance on deferred pastures of Brachiaria brizantha and Brachiaria decumbens. Ciência Rural, v. 46, n. 11, p. 1998-2004, 2016. Disponível em: <https://doi.org/10.1590/0103-8478cr20151525>. Acesso em: 20 maio 2020.

SOUSA, B. M. DE L.; VILELA, H. H.; SANTOS, A. L.; SANTOS, M. E. R.; NASCIMENTO J. R. D.; ASSIS, C. Z. DE; FARIA, B. D.; ROCHA, G. de O. Piata palisadegrass deferred in the fall: effects of initial height and nitrogen in the sward structure. Revista Brasileira de Zootecnia, v. 41, n. 5, p. 1134-1139, 2012. Disponível em: <https://doi.org/10.1590/S1516-35982012000500008>. Acesso em: 20 maio 2020.

UNIVERSIDADE FEDERAL DE VIÇOSA - UFV. SAEG - Sistema de análises estatísticas e genéticas. Versão 8.1. Viçosa, MG: 2003. (Apostila).

VILELA, H. H.; SOUSA, B. M. DE L.; SANTOS, M. E. R.; SANTOS, A. L.; ASSIS, C. Z. de; ROCHA, G. de O.; FARIA, B. D.; NASCIMENTO JR, D.; NASCIMENTO JR, D. DO. Forage mass and structure of piatã grass deferred at different heights and variable periods. Revista Brasileira de Zootecnia, v. 41, n. 7, p. 1625-1631, 2012. Disponível em: <https://doi.org/10.1590/S1516-35982012000700010>. Acesso em: 20 maio 2020. 